\title{
DISCURSO E RELAÇÕES DE PODER EM LAVOURA ARCAICA, DE RADUAN NASSAR
}

\author{
Alex Fabiano Correia Jardim* \\ Jacqueline Ribeiro de Souza**
}

\begin{abstract}
Resumo: A proposta do artigo é tratar da questão do discurso e das relações de poder na obra Lavoura Arcaica, de Raduan Nassar. Pretendemos desenvolver o texto fazendo uma tessitura com o pensamento de Michel Foucault (saber, poder, discurso). No romance, apresentaremos, em especial, o embate entre pai e filho, ambos representando formas particulares de modos de vida, indicando nos aspectos antitéticos que perpassam a narrativa: o sagrado e o profano, tradição e modernidade, razão e paixão. Tanto na literatura de Raduan Nassar, como no pensamento de Michel Foucault, o sujeito é constituído em função dos discursos e do exercício de poder que o envolve e o implica, fabricando corpos e produzindo identidades. É esse sujeito e a sua possível dissolução que será nosso objeto.
\end{abstract}

Palavras-chave: Saber. Poder. Discurso. Sujeito. Transgressão.

INTRODUÇÃO

\begin{abstract}
Tinha contundência o meu silêncio!
Tinha textura a minha raiva!

Raduan Nassar
\end{abstract}

O que propomos neste texto é analisar a obra Lavoura Arcaica (2005), de Raduan Nassar, tendo como problema elementos internos do texto que podem fazer uma intercessão com alguns conceitos de Michel Foucault, em especial, a questão do discurso e das relações de poder. A ideia não é necessariamente fazer uma interlocução, mas apontar que alguns conceitos foucaultianos podem nos servir para pensar aspectos do romance. A propósito, a ideia é apresentar uma implicação ou um encontro possível entre alguns conceitos filosóficos, o texto nassariano e o mundo dos seus personagens, compondo entre eles (Nassar e Foucault) um tipo de teia, onde cada um à sua maneira, nem por isso díspares, apresentam problemas que envolvem diretamente a existência e suas relações.

É importante, já de início, destacarmos que o romance nos apresenta uma série de perspectivas que vão desde um conflito entre pai e filho, até conflitos entre irmãos, mas, não obstante, também nos apresenta a possibilidade de uma analítica em torno da relação entre o sagrado e o profano, a tradição e a modernidade. É a partir desses binarismos e do embate entre eles que apontaremos os elementos que compõem o

\footnotetext{
* Doutor em Filosofia pela Universidade Federal de São Carlos (UFSCAR). Professor da Universidade Estadual de Montes Claros (UNIMONTES). E-mail: alex.jardim38@hotmail.com.

** Doutoranda em Estudos Linguísticos pela Universidade Federal de Uberlândia (UFU). Tutora no Instituto Federal do Norte de Minas Gerais (IFNMG).
} 
fundamento da família, esta, instituição por excelência, de forte apelo religioso, teológico e disciplinar. Será numa disputa, em especial entre pai e filho, que nos debruçaremos com mais atenção neste texto. Numa clara alusão à parábola do filho pródigo, Raduan Nassar apresenta-nos um movimento que vai da partida de um filho, os sentimentos deixados para trás, à ruptura com a família. Abordaremos como o romance é marcado por um jogo de exercício de poder entre André (o filho) e seu pai (Iohanna), realçando uma violência contagiada por um pensamento delirante, cada um ao seu modo e à sua maneira expondo o conjunto de (des)razão que os move. Se por um lado temos o discurso do Pai, chefe e senhor, qualificado historicamente enquanto portador de uma verdade universal, garantindo-lhe a palavra, a verdade e o poder; do outro lado, deparamo-nos com o filho: revolto, anormal, disjuntivo e a-lógico, impulsionado e envolvido pelo desejo à irmã (Ana). Sentimentos que exprimem a degenerescência máxima do espírito e da moral, além de um profundo mergulho no profano.

\section{$1^{\circ}$ ASPECTO: UMA APRESENTAÇÃO GERAL DA OBRA}

O romance já se inicia com a apresentação e descrição da cena de um encontro entre dois irmãos, André e Pedro. Desde o início do romance, já observamos um embate entre os dois irmãos. André, atormentado por um amor transgressor e que destoa de uma vida moral constituída pela tradição e por uma racionalidade que conduz a modos de vida disciplinar e reto. André é um torto. Pedro, pelo contrario, é a voz e o espelho de um Pai que conduz a vida de todos em função de uma crença, de um dogma: o respeito ao passado da família e à palavra de Deus. Pedro é imagem da representação que carrega em seus ombros os pressupostos que constituem uma existência ou regimes de vida. Pedro é o olho do pai, a pura afinação entre a verdade e o discurso moral.

Esse encontro entre os dois irmãos se dá num misto de fluxo da palavra e do silêncio; entre o discurso e a contemplação que margeia ambos, há uma inconteste luta pelo estabelecimento de uma verdade. No caso de Pedro, seu discurso de verdade é estabelecido pela tentativa de produção de culpa em André. E no caso de André, a verdade deve ser demolida em favor de uma crítica dura e mordaz acerca dos costumes, da autoridade, do supostamente sagrado.

Para Pedro, maciço de pedra talhada pelo pai, o bem e o amor devem ser os pressupostos para uma boa natureza do pensamento. Por outro lado, André, enquanto árvore torta e anômala, o contrapõe, tentando se livrar das formas de representação que até então o constituiu. Enquanto imagem deformante do pensamento, André apresenta as razões de sua perdição, guardando ainda em silêncio o motivo maior: o incesto com Ana, sua irmã. E nesse jogo, a memória enquanto lembrança pura exerce um papel importante, pois ela será o fio do tempo que faz contrair a cada palavra novas percepções, novas perspectivas de mundo. Desde já, é possível notarmos que o discurso de André é incompreensível para Pedro, pois se para o primeiro a verdade é movida e sustentada em função de sua experiência-limite, em Pedro ela se encontra protegida pela carapaça da moral, impossibilitando que adentre no labirinto por onde André agora caminha, se perde e se reencontra. São os labirintos do seu corpo, da sua lembrança, do seu amor, do seu pensamento desmedido e desfigurado. 
A partir do capítulo 3, torna-se mais intensa a relação entre a representação e a memória, afinal, a primeira forja no espírito, e este, por extensão, no corpo, a marca indelével do código, da regra, da lei. E o que era o corpo de André? O que ele podia? Quais as afecções que o afligiam e o tornavam tenebroso, confuso, perdido? A experiência-limite do caos o fez traçar uma nova linha. O recolhimento numa pensão, venezianas fechadas, quarto escuro. E André é quem nos diz: “[...] eu estava escuro por dentro, não conseguia sair da carne dos meus sentimentos" (NASSAR, 2005, p. 13).

Diante das leis da sobriedade da razão, a construção da narrativa de Nassar também nos confronta com o inevitável da desrazão. O pensamento em André é movido não somente pelo amor transgressor, mas também pela cólera em relação aos costumes, aos hábitos que edificam uma moral. Um discurso sempre implicado com a verdade. Como afirmou Perrone-Moisés: "a cólera é a paixão dos impacientes, curioso paradoxo se nos lembrarmos que a palavra paixão e a palavra paciência têm a mesma etimologia: passio, isto é, sofrimento" (2001, p. 61). E a impaciência é a força motriz que leva André à vertigem do corte, "a impaciência também tem os seus direitos!" (NASSAR, 2005, p. 88). A família, santuário puro da verdade, da união e do trabalho, onde cada um deveria, imperativamente, fazer a sua parte, resguardar seu papel, cumprir a sua lei. Um tipo de cuidado de si e dos outros, sem desvio, sem desejos particulares. Era esse o discurso do Pai, catedral da verdade:

\begin{abstract}
Pois se condenava a um fardo terrível aquele que se subtraísse às exigências sagradas do dever; ele falou ainda dos anseios isolados de cada um em casa, mas que era preciso refrear os maus impulsos, moderar prudentemente os bons, não perder de vista o equilíbrio, cultivando o autodomínio, precavendo-se contra o egoísmo e as paixões perigosas que o acompanham, procurando encontrar a solução para os nossos problemas individuais sem criar problemas mais graves para os que eram de nossa estima [...] (NASSAR, 2005, p. 22).
\end{abstract}

É diante desse quadro que André se impacienta. Se, por um lado, temos a parcimônia e temperança da razão (Pai), do outro, teremos a densidade da impaciência e da cólera (Filho). É nesse confronto que o romance se desdobra. Entre a partida e o retorno, o passado e o presente, não haverá mais harmonia e nem a esperança de um recomeço. Pelo contrario, é justamente o passado que feriu André com suas marcas imperceptíveis aos olhos da família: a paixão por Ana.

\footnotetext{
Ana, impaciente, impetuosa, o corpo de campônia, a flor vermelha feito um coalho de sangue prendendo de lado os cabelos negros e soltos, essa minha irmã que, como eu, mais que qualquer outro em casa, trazia a peste no corpo, ela varava então o circulo que dançava e logo eu podia adivinhar seus passos precisos de cigana se deslocando no meio da roda, desenvolvendo com destreza gestos curvos entre as frutas, e as flores dos cestos, só tocando a terra na ponta dos pés descalços, os braços erguidos acima da cabeça serpenteando lentamente ao trinado da flauta mais lento, mais ondulante [...] (NASSAR, 2005, p. 29).
}

Mas meus olhos cheios de amargura não desgrudavam de minha irmã que tinha as plantas dos pés em fogo imprimindo marcas que queimavam dentro de mim... que poeira clara, vendo então as costas daquele tempo decorrido, o mesmo tempo que eu um dia, os pés acorrentados, abaixava os olhos para não ver-lhe a cara. (NASSAR, 2005, p. 31-32). 
O passado faz de André um desmedido em que a perversão encontra morada. Escapando-se à filiação em relação ao verdadeiro, André não se arrepende da acusação de promover a discórdia. Se ele aceita o discurso do Pai é para aliviar o cansaço dos apelos do corpo: reprimido e torcido por gritar suas vontades. Este corpo, conduzido até então pelos enunciados sempre negativos da tradição: o corpo da família, dos objetos da casa, das regras, do pai, de Pedro. Toda essa organização sintetizada na lei paterna é arruinada por André na ocasião de um golpe fatal, a paixão por Ana levada ao extremo pelo incesto. André consegue, a partir de uma disjunção, provocar fissuras nesses vários corpos, afinal, seu corpo é a-significado. Corpo dessemelhante. Diferencial. Obscuro. Espasmo vertiginoso de uma forma de vida que rompia com a sua velha identidade de filho-cordeiro:

\begin{abstract}
[...] Fui explodindo, convulsionado mais do que nunca pelo fluxo violento que me corria o sangue "um epilético" eu berrava e soluçava dentro de mim, sabendo que atirava numa suprema aventura ao chão, descarnando as palmas, o jarro da minha velha identidade elaborado com o barro das minhas próprias mãos, e me lançando nesse chão de cacos, caído de boca num acesso louco fui gritando "você tem um irmão epilético, fique sabendo, volte agora pra casa e faça essa revelação, volte agora e você verá que as portas e janelas lá de casa hão de bater com essa ventania ao se fecharem e que vocês, homens da família, carregando a pesada caixa de ferramentas do pai, circundarão por fora a casa encapuçados, martelando e pregando com violência as tabuas em cruz contra as falhas das janelas, e que nossas irmãs de temperamento mediterrâneo e vestidas de negro hão de correr esvoaçantes pela casa em luto e será um coro de uivos, soluços e suspiros nessa dança familiar trancafiada e uma revoada de lenços pra cobrir os rostos e chorando e exaustas elas hão de amontoar-se num só canto e você grite cada vez mais alto 'nosso irmão é um epilético, um convulso, um possesso"” (NASSAR, 2005, p. 40).
\end{abstract}

Esse "eu fendido ou fissurado" de André degrada o ideal de mundo pelo viés da sexualidade perversa. Teremos então a lógica do absurdo ou do non sense. O que faz dele um diferente? Que crime hediondo ele cometeu? Algo ocorre de tal maneira que André salienta seu desvio. Sua individuação. Algo se passou de tal forma que outrora o espaço, o corpo-estrutura que constitui a tradição e o tempo, curso regular e cíclico, tornam-se desprovidos de uma docilidade ou contiguidade. E é o amor perverso que a tudo muda. Tudo dissolve. "amar e ser amado era tudo o que eu queria" (NASSAR, 2005, p. 137). E no romance, este amor é uma des-natureza. Se o amor transgressor ocorre no cenário familiar é para indicar-nos que a tradição: lar, trabalho, autoridade patriarcal, religiosidade, são empecilhos para saciar a sede do corpo, e André justifica e insiste em dizer a Pedro, seu irmão:

\footnotetext{
Não tenho culpa desta chaga, deste cancro, desta ferida, não tenho culpa deste espinho, não tenho culpa desta intumescência, deste inchaço, desta purulência, não tenho culpa deste osso túrgido, e nem da gosma que vaza pelos meus poros, e nem deste visgo recôndito e maldito, não tenho culpa deste sol florido, desta chama alucinada, não tenho culpa do meu delírio [...] (NASSAR, 2005, p. 136).
}

Mas não é apenas desse amor transgressor que o texto nassariano trata. Há também em seu interior a indicação de uma identidade que vai se dissolvendo num duro e penoso processo de desconstituição de si. Vimos isso claramente no capítulo 7 da 
obra, onde o personagem André, numa série de interrogações, nos indica as dúvidas e incertezas características de quem destruiu de alguma maneira antigos pilares que davam ao mundo forma e conteúdo:

\footnotetext{
Onde eu tinha a cabeça? Que resinas se dissolviam na danação do espaço, me fustigando sorrateiras a relva delicada das narinas? Que salto, que potro inopinado e sem sossego correu com meu corpo em galope levitado? (NASSAR, 2005, p. 48-49)
}

Concomitante a essas interrogações, André intensifica seus sentimentos em relação às formas históricas e culturais de sua formação ao afirmar as maneiras e procedimentos em que o seu Pai estabelecia o seu domínio na família, como no diálogo com seu irmão Pedro:

\begin{abstract}
Tudo em nossa casa é morbidamente impregnado da palavra do pai; era ele, Pedro, era o pai que dizia sempre, é preciso começar pela verdade e terminar do mesmo modo, era ele sempre dizendo coisas assim, eram pesados aqueles sermões de família, mas era assim que ele os começava sempre, era essa a sua palavra angular, era essa a pedra em que tropeçávamos quando crianças, essa a pedra que nos esfolava a cada instante, vinham ai as nossas surras e as nossas marcas no corpo [...] (NASSAR, 2005, p. 41).
\end{abstract}

Outro exemplo que caracterizava a identidade dos membros da família no texto nassariano era a sua disposição à mesa de refeição. Teremos dois polos representados pela distribuição de todos à mesa do pai: o polo da tradição, do conservadorismo, da temperança, do autocontrole e da moderação, na figura do patriarca e seus seguidores: as filhas (menos Ana) e, em especial, Pedro, o filho mais velho; e o polo da libertação, do descontrole, dos pequenos segredos e do descomedimento, representado pela mãe e seus respectivos seguidores: André, Ana e Lula, estes à esquerda do pai.

Responsável pela continuidade da família e de perpetuar os ensinamentos herdados, não quebrando o círculo de uma tradição secular, o pai Iohána tenta, de forma imperativa, impor aos membros de sua família regras e valores - o discurso como forma de produzir corpos e dar aos mesmos um estatuto. Essa estrutura estabelece contornos e formas que são reduzidas à consciência patriarcal como se essa consciência correspondesse a um plano transcendental. Nesse caso, é como se afirmássemos que as leis, a moral, as regras do pai funcionassem como um conjunto ordenado em que a "sua" consciência promovesse uma síntese constitutiva universal. De acordo com Jurandir Freire Costa, a castração pela linguagem pode ser entendida como as várias formas de ensinar os sujeitos a seguirem regras morais, estruturando suas subjetividades de acordo com os ideais de eu e seu comportamento. Porém, essa construção de subjetividades ideais implica, "ipso facto, a figura da antinorma ou do desvio do ideal, representada pelos que não podem, não sabem ou não querem seguir as injunções ideais" (COSTA, 1992, p. 19). Entendemos, portanto, que a tentativa do pai de moldar e disciplinar os familiares, visando a construção de subjetividades ideais, influencia na construção de discursos de desvio desse ideal, comum àqueles que estão à sua esquerda, ou seja, resistências vão sendo suscitadas em meio aos processos de subjetivação. 
André pronuncia duas frases importantes no texto que nos servirão para compreender o que envolve o confronto com a tradição: "não reconheço mais os valores que me esmagam" (NASSAR, 2005, p. 162). "A única coisa que sei é que todo meio é hostil, desde que negue direito à vida" (NASSAR, 2005, p. 165). Obviamente que num sentido oposto, todo o esforço do Pai é por marcar poder, dar um pouco de ordem ao caos. "Já basta de extravagâncias, não prossiga mais neste caminho, não se aproveitam teus discernimentos, existe anarquia no teu pensamento, ponha um ponto na tua arrogância, seja simples no uso da palavra" (NASSAR, 2005, p. 166). Opondo-se insistentemente ao pai, André, de maneira ingênua, se ilude acreditando que poderia estabelecer um diálogo entre a tradição e novo. Entre uma consciência constituinte (seu pai) e um "eu" (si mesmo) que a cada mergulho na palavra se deforma e se dissolve, escapando-se na medida do possível das construções históricas que o determinam e moldaram a sua forma:

[...] Pertenço como nunca desde agora a essa insólita confraria dos enjeitados, dos proibidos, dos recusados pelo afeto, dos sem-sossego, dos intranquilos, dos inquietos, dos que se contorcem, dos aleijões com cara de assassino que descendem de Caim (quem não ouve a ancestralidade cavernosa dos meus gemidos?), dos que trazem um sinal na testa, essa longínqua cicatriz de cinza dos marcados pela santa inveja, dos sedentos de igualdade e de justiça, dos que cedo ou tarde acabam se ajoelhando no altar escuso do Maligno, deitando antes em sua mesa, piamente, as despojadas oferendas: uma posta de peixe alva e fria; as uvas pretas de uma parreira na decrepitude, os algarismos solitários das matemáticas, as cordas mudas de um alaúde, um punhado de desespero, e um carvão solene para os seus dedos criadores, a ele, o artífice do rabisco, o desenhista provecto do garrancho, o artesão que trabalha em cima de restos de vida, puxando no traço de sua linha a vontade extenuada de cada um, ele, o propulsor das mudanças, nos impelindo com seus sussurros contra a corrente, nos arranhando os tímpanos com seu sopro áspero e quente, nos seduzindo contra a solidez precária da ordem, este edifício de pedra cuja estrutura de ferro é sempre erguida, não importa a arquitetura, sobre os ombros ulcerados dos que gemem, ele, o primeiro, o único, o soberano, não passando o teu Deus bondoso (antes discriminador, piolhento e vingativo) de um vassalo, de um subalterno, de um promulgador de tabuas insuficiente, incapaz de perceber que suas leis são a lenha resinosa que alimenta a constância do Fogo Eterno! Não basta o jato da minha cusparada, contenha este incêndio enquanto é tempo, já me sobe uma nova onda, já me queima uma nova chama, já sinto ímpetos de empalar teus santos, de varar teus anjos tenros, de dar uma dentada no coração de Cristo! (NASSAR, 2005, p. 138-139).

A dissolução do sujeito-André passa necessariamente por um tipo de destruição do passado. Nos diálogos que protagoniza, seja com Pedro (seu irmão mais velho), o Pai ou Ana, André descreve de maneira irônica e crítica o bom sentido das coisas e sua pressuposta evidência lógica. E é nesse itinerário narrativo, forjado sob a raiva, a ironia e o sarcasmo, que André torna infértil o terreno onde foi semeada a pálida obsessão pela virtude. Se por um lado teremos o discurso negativo da paixão, despejado sob a forma do jorro verbal e autoritário de um patriarca, por outro lado, o corpo e a língua quente e sedenta de André, pouco pródigo, enfatizam sua travessia, revelando os segredos silenciosos, proibidos, desautorizados e estranhos. Se o pai diz:

O mundo das paixões é o mundo do desequilíbrio, é contra ele que devemos esticar o arame das nossas cercas, e com as farpas de tantas fiadas tecer um crivo estreito, e sobre este crivo emaranhar uma sebe viva, cerrada e pujante, que dividia e proteja a luz calma e clara da 
nossa casa, que cubra e esconda dos nossos olhos as trevas que ardem do outro lado; e nenhum entre nos há de transgredir esta divisa, nenhum entre nos há de estender sobre ela sequer a vista, nenhum entre nos há de cair jamais na fervura desta caldeira insana, onde uma química frívola tenta dissolver e recriar o tempo [...] (NASSAR, 2005, p. 55).

André não corrobora com tal impressão, basta observarmos a declaração que ele faz a Pedro:

\begin{abstract}
Era Ana, era Ana, Pedro, era Ana a minha fome, explodi de repente num momento alto, expelindo num só jato violento meu carnegão maduro e pestilento. Era Ana a minha enfermidade, ela a minha loucura, ela o meu respiro, a minha lâmina, meu arrepio, meu sopro, o assédio impertinente dos meus testículos, gritei de boca escancarada [...]. Eu tinha de gritar em furor que a minha loucura era mais sabia que a sabedoria do pai, que a minha enfermidade me era mais conforme que a saúde da família, que os meus remédios não foram jamais inscritos em compêndios, mas que existia uma outra medicina (a minha!), e que fora de mim eu não reconhecia qualquer ciência, e que era tudo só uma questão de perspectiva [...] (NASSAR, 2005, p. 107-109).
\end{abstract}

\title{
DISCURSO E PODER:
}

\section{O PROBLEMA DA SUBJETIVIDADE - UMA INTERCESSÃO FOUCAULTIANA}

Ao analisarmos a construção dos sujeitos em Lavoura Arcaica, é possível apresentarmos as disparidades discursivas presentes nos discursos do pai e dos membros familiares que se encontram à sua esquerda; uma sorte de antinorma promovida pelos que tentam romper com a tradição e com a ordem. Os que estão "do lado esquerdo" passam a estabelecer uma relação de força e de poder com o patriarca. Estabelece-se uma resistência.

Nessa perspectiva, o discurso pode ser entendido como qualquer atividade produtora de sentido entre os interlocutores no processo da enunciação, e é regulado por uma exterioridade linguística que é o contexto histórico-social e a ideologia. O sentido de uma enunciação depende do locutor e do interlocutor, eles são os sujeitos da interação comunicativa. Esse sujeito do discurso é, na verdade, uma imagem que está ligada à formação histórica e ideológica, e como imagem pode se revelar ou se omitir, ocupando diversas posições e diferentes papéis sociais. O sujeito é, portanto, um efeito do discurso, visto que é no discurso que ele é constituído. A subjetividade, dessa forma, trata da capacidade de o indivíduo se colocar como sujeito, referindo-se a ele mesmo com o emprego do eu no seu discurso. Vejamos o que nos diz Benveniste:

\footnotetext{
$\mathrm{O}$ eu se refere ao ato de discurso individual no qual é pronunciado, e lhe designa o locutor. É um termo que não pode ser identificado a não ser dentro do que, noutro passo, chamamos uma instância de discurso, e que só tem referência atual. A realidade à qual ele remete é a realidade do discurso. É na instância de discurso na qual eu designa o locutor que este se enuncia como "sujeito" (BENVENISTE, 1995, p. 288).
} 
Para Michel Foucault (2005), o discurso é uma prática que provém da formação de saberes e que necessita de uma articulação com outras práticas não discursivas; é um jogo estratégico e polêmico de ação e reação, de dominação e de esquiva; é um espaço em que o saber e o poder se articulam, já que aquele que fala, fala de algum lugar, a partir de um direito reconhecido institucionalmente, sendo que a produção do discurso gerador de poder é controlada, selecionada, organizada e redistribuída por procedimentos que visam a eliminar toda e qualquer ameaça a esse poder. Dessa forma, o sujeito está preso a essas relações complexas de poder, que devem ser vistas a partir das estratégias de poder/resistência. É importante destacar que essas relações de poder são caracterizadas muito mais pela produção do que pela repressão, ou seja, possuem uma positividade (constituem comportamentos, ideias, práticas e modos).

Por isso o discurso está longe de ser algo neutro, pelo contrário, as interdições impostas a ele revelam rapidamente sua ligação com o desejo e o poder. O discurso não é simplesmente a manifestação ou ocultação do desejo, é também o objeto do desejo; como também não é só a tradução dos sistemas de dominação, mas também aquilo pelo qual se luta, "o poder do qual nos queremos apoderar." (FOUCAULT, 2005, p. 10). O discurso é, portanto, alvo de desejo e símbolo de poder. E o sujeito, enquanto produto dos discursos, é efeito e alvo do exercício do poder, este não compreendido como localizado nas mãos de alguém ou de algum ponto específico da estrutura social. Apresenta-se muito mais como uma relação. E é seu caráter relacional que implica ao mesmo tempo luta e resistência pelo seu exercício. Nada, nem ninguém, está isento de poder. Ele se exerce, funciona, disputa-se.

\footnotetext{
Não existem de um lado os que têm o poder e de outro aqueles que se encontram dele alijados. Rigorosamente falando, o poder não existe; existem sim práticas ou relações de poder. O que significa dizer que o poder é algo que se exerce, que se efetua e que funciona. E funciona como uma maquinaria, como uma máquina social que não está situada em um lugar privilegiado ou exclusivo, mas se dissemina por toda a estrutura social. Não é um objeto, ou uma coisa, mas uma relação. (FOUCAULT, 1984: XIV).
}

Essa nova noção de poder surge nas análises e pesquisas de Foucault e é bastante útil para podermos pensar a construção da subjetividade no ambiente familiar de Lavoura Arcaica, já que se trata de um espaço estratégico para o exercício do poder e, consequentemente, para a modelização dos sujeitos através de um discurso que investe sobre os corpos.

O pai, em Lavoura Arcaica, é aquele que procura exercer o poder de dominação dos membros familiares, controlando-os e administrando-os. Tenta, através do seu discurso, formalizar o indivíduo desautorizando seu desejo, sua vontade e sua autonomia. Dessa forma, posiciona-se como autoridade suprema e tenta eliminar qualquer ameaça a seu 'poder' enquanto lugar de fala. Poder até então visto pelo Pai enquanto posse e propriedade (ele possui o direito ao discurso). No entanto, as verdades instituídas estimulam a produção de discursos de resistência. Dessa forma, as relações de poder e de resistência se intensificam, produzindo pensamentos, palavras e atitudes que transgridem o discurso paterno, sendo essa transgressão comum não só a André, mas também à mãe, Ana e Lula, ou seja, os representantes do lado esquerdo da família. 
E é pensando nessas complexas relações de poder que podem estimular e intensificar a produção de resistência, presentes em Lavoura Arcaica, que pontuamos a importância de atentar para um fator de grande relevância: o processo narrativo. De acordo com Maurice Blanchot:

\begin{abstract}
Narrar não é uma evidência. O ato narrativo, como se sabe, geralmente é assumido por tal ou tal personagem, não porque este, ao narrar diretamente, faça-se o narrador de uma história já vivida ou que se está vivendo, mas porque ele constitui o centro a partir do qual a perspectiva da narrativa se organiza: tudo é visto desse ponto de vista. (BLANCHOT, 2010, p. 146).
\end{abstract}

O autor citado chama a atenção para a existência de um 'eu' privilegiado da narrativa, aquele que determina a perspectiva do romance imprimindo um ponto de vista que não coincide necessariamente com a totalidade de uma consciência. $\mathrm{O}$ narrar não equivale à transparência dos fatos. Dessa maneira, verificamos que em Lavoura Arcaica o 'eu' privilegiado da narrativa é André, personagem que impõe resistência ao discurso de saber e poder do pai. De forma convulsa e epilética, ele conta sua história de maneira subjetiva e limitada à sua perspectiva. Por ser um narrador em primeira pessoa, sua narrativa é contaminada e impregnada pelo seu ponto de vista, sendo incapaz de narrar os fatos com imparcialidade, exigindo, assim, uma maior atenção do leitor, uma vez que tudo o que é narrado pode ser questionado. De acordo com Oscar Tacca, "é sabido que o verdadeiro estilo de um narrador não consiste tanto no que conta (os temas vão e vêm), mas em como conta." (TACCA, 1983, p. 67). Nesse sentido, acreditamos que André, na sua forma de narrar, figura-se como um narrador enganoso que quer levar à morte do pai, não à morte no sentido literal da palavra, mas à morte figurada, em que o pai, perdendo o seu posto de sujeito de enunciação, sujeito no exercício da lei e da sabedoria, tem sua morte determinada.

É na instância do discurso que o homem é instituído como sujeito. É, portanto, através do seu discurso firme e austero que Iohána se impõe como senhor supremo do seu clã, alternando funções como as de chefe, sacerdote e juiz, ou seja, todas as funções implícitas às tarefas de um pai. Já que exerce o direito privilegiado e exclusivo do sujeito que fala, vê-se no direito e na posição de impor, julgar e punir. Dessa forma, é no discurso que desempenha que se manifesta de forma mais efetiva seu poder, basta prestarmos atenção ao verbo áspero do pai que se fazia presente em todas as manhãs e noites na mesa dos sermões. Uma regularidade de procedimento, ilustrada pela solenidade do momento, como, por exemplo, quando falou da importância e supremacia do tempo:

\footnotetext{
Onipresente, o tempo está em tudo; existe tempo, por exemplo, nesta mesa antiga: existiu primeiro uma terra propícia, existiu depois uma árvore secular feita de anos sossegados, e existiu finalmente uma prancha nodosa e dura trabalhada pelas mãos de um artesão dia após dia. (NASSAR, 2005, p. 52).
}

O tempo em seu discurso é um bem supremo e tesouro precioso, cultuado como o bem maior que deve ter seu fluxo respeitado para se chegar ao equilíbrio. Repreende aos 
demais, informando que, na sua casa, ninguém há de dar um passo maior que a perna, que ninguém há de colocar o carro na frente dos bois, bem como nunca começar nada pelo teto; adverte que aquele que agir assim, de forma a impacientar o tempo, não construirá suas bases de sustentação para manter tal equilíbrio. É preciso seguir rigorosamente a lei maior: "a obediência absoluta à soberania incontestável do tempo" (NASSAR, 2005, p. 57). Submeter-se à soberania do tempo seria para o pai uma forma de conservação do status quo familiar. Consoante Lima, "a submissão respeitosa ao tempo garantiria a manutenção de uma regularidade estável, evitando que algum membro do grupo se rebelasse contra essa ordem." (LIMA, 2006, p. 21).

Ao falar do tempo, percebemos também, por parte do pai, uma valorização do passado, e conseguintemente dos antepassados, pois tudo que existe hoje exigiu, anteriormente, esforço e trabalho de outras pessoas. Notamos, dessa maneira, mais uma tentativa de manutenção da ordem familiar e da estrutura patriarcal através do culto aos antepassados, figurado na presença do tempo. Não contestar o tempo e o que ele institui pode ser entendido como a soberania incontestável da tradição. Para Abati, o pai seria uma espécie de "representante e guardião das doutrinas herdadas, contribuindo com sua lavoura arcaica para a perpetuação do saber ancestral." (ABATI, 1999, p. 60).

Sempre agarrado à tradição, o Iohána presta em seus sermões um culto à sabedoria dos mais velhos, chamando a atenção para que a família não se esqueça nunca das suas origens, por isso mantém junto à mesa de refeições, na outra cabeceira, uma cadeira vazia em homenagem ao seu pai. Destaca ainda que, a exemplo dos mais velhos, a primeira lei da casa deve ser a paciência que, cultivada com muito zelo pelos antepassados, funciona como uma espécie de viga de suporte para os momentos de adversidade. Ou seja, todo o discurso é direcionado à manutenção de uma ordem, daí a necessidade dos procedimentos que instituem códigos, práticas e sujeitos. Enfim, para ele, "hão de ser esses, no seu fundamento, os modos da família: 'baldrames bem travados, paredes bem amarradas, um teto bem suportado"” (NASSAR, 2005, p. 60). Com isso, o narrador nos dá a perceber que o pai se utiliza de procedimentos de exclusão e de controle para manter-se no poder, à frente da família. Segundo Foucault (2005), os procedimentos de exclusão seriam a interdição, a separação ou a rejeição e o discurso da verdade.

Para Michel Foucault (2005), o discurso é uma prática que provém da formação de saberes e que necessita de uma articulação com outras práticas não discursivas; é um jogo estratégico e polêmico de ação e reação, de dominação e de esquiva; é um espaço em que o saber e o poder se articulam, já que aquele que fala, fala de algum lugar, a partir de um direito reconhecido institucionalmente; neste caso, a produção do discurso gerador de poder é controlada, selecionada, organizada e redistribuída por procedimentos que visam eliminar toda e qualquer ameaça a esse poder. Dessa forma, o sujeito está preso a essas relações complexas de poder, que devem ser vistas a partir das estratégias de poder e resistência. É importante destacar que essas relações de poder são caracterizadas muito mais pela produção do que pela repressão, uma vez que produzem pensamentos, ideias, palavras e comportamentos. Segundo Foucault, em uma sociedade como a nossa, existem procedimentos de exclusão e o mais conhecido de todos eles seria a interdição. "Sabe-se que não se tem o direito de dizer tudo, que não se pode falar 
de tudo em qualquer circunstância, que qualquer um, enfim, não pode falar de qualquer coisa" (FOUCAULT, 2005, p. 9). Isso evidencia que aquele que fala detém, de certa forma, um direito exclusivo e privilegiado, como podemos verificar no romance através do personagem Iohána.

O primeiro procedimento é a interdição. O mais familiar meio de exclusão, formado por uma grade complexa que envolve o tabu do objeto, ritual da circunstância e direito privilegiado e exclusivo do sujeito que fala. No romance, esse princípio é utilizado pelo pai ao proibir aos familiares ultrapassar os limites da fazenda, abrir-se para as paixões e os desejos, impondo-lhes o comedimento. É preciso afastar-se do mundo das paixões porque é ele o mundo das trevas e do desequilíbrio. É necessário "erguer uma cerca ou guardar simplesmente o corpo" (NASSAR, 2005, p. 56), pois é somente através do recolhimento que se consegue fugir do perigo das paixões. Bem como lhes proíbe o direito à fala, pois somente a ele é dado esse direito, aos outros cabe simplesmente a aceitação e a repetição dos seus preceitos.

Outro princípio também usado pelo pai é o princípio da separação ou rejeição. Conforme Foucault, este procedimento é caracterizado pela oposição entre a razão e a loucura, verdade e falso, normal e anormal. Para o pai, aquele que contraria os seus desígnios blasfema, já que seu discurso sagrado, construído na base de uma tradição milenar, é o discurso da razão, e qualquer indivíduo que venha contrapor-se a essa razão será tomado como louco. E o discurso do louco deve ser impedido de circular.

O discurso da verdade, como terceiro sistema de exclusão, impõe uma separação entre o verdadeiro e o falso, e essa separação é histórica e institucionalmente constituída e não se exerce sem pressão ou violência. Essa produção de verdade está totalmente ligada ao poder e seus mecanismos e dispositivos. Esses mecanismos de poder tornam possível a produção de verdade, bem como a própria produção de verdade tem efeitos de poder sobre os indivíduos. Dessa maneira, as relações entre verdade/poder e saber/poder são indissociáveis. É notório no romance como os mecanismos de controle dos discursos são utilizados pelo pai. Esses procedimentos de controle tratam de determinar as condições de seu funcionamento, impondo regras e não permitindo que todos tenham acesso a ele. Conforme Foucault, "ninguém entrará na ordem do discurso se não satisfizer a certas exigências ou se não for, de início, qualificado para fazê-lo." (FOUCAULT, 2005, p. 37). A forma mais visível desse sistema de restrição é o ritual, dado que ele:

\footnotetext{
Define a qualificação que devem possuir os indivíduos que falam (e que, no jogo do diálogo, da interrogação, da recitação, devem ocupar determinada posição e formular determinado tipo de enunciados); define os gestos, os comportamentos, as circunstâncias, e todo o conjunto de signos que devem acompanhar o discurso; fixa, enfim, a eficácia suposta ou imposta das palavras, seu efeito sobre aqueles aos quais se dirigem, os limites de seu valor de coerção. (FOUCAULT, 2005, p. 39).
}

Basta vermos, para corroborar a afirmação acima, que Iohána, em seus sermões, seguia sempre o mesmo ritual, a fim de que a família fixasse suas palavras e internalizasse o seu código de conduta: "o excesso proibido, o zelo uma exigência, e, condenado como vício, a prédica constante contra o desperdício, apontando sempre 
como ofensa grave ao trabalho" (NASSAR, 1989, p. 75-76). André relata que esse ritual de austeridade se cumpria três vezes ao dia, na hora de repartir o pão, principalmente na mesa de refeições, lugar onde faziam o aprendizado da justiça do pai. Esse ritual se completava com gestos, comportamentos e signos que acompanhavam os sermões do patriarca. O pai sempre à cabeceira fazia uma pausa de costume para que refletissem sobre suas palavras e, segundo André, medissem a "majestade rústica" de sua postura: firme, solene, pescoço sólido, cabeça grave e as mãos prendendo a quina da mesa. É isso efetivamente o que Foucault está denominando de "ritual".

A doutrina também é um procedimento de controle dos discursos. Com tendência a difundir-se, caracteriza-se pela partilha entre os indivíduos de um só e mesmo discurso. Ela "liga os indivíduos a certos tipos de enunciação e lhes proíbe, consequentemente, todos os outros." (FOUCAULT, 2005, p. 43). Em Lavoura Arcaica, o pai impetra ao seu discurso esse traço doutrinário, porquanto pretende que a família partilhe o mesmo discurso que ele, proibindo qualquer outro discurso que não seja o seu. Também pretende que seus ensinamentos sejam difundidos e repassados pelos filhos. Percebemos esse desejo de perenidade quando mantém viva a memória dos antepassados, exaltando a todo o momento a sabedoria dos mais velhos. Se hoje ele colhe o que semearam antes, um dia colherão daquilo que ele semeia hoje.

Outro procedimento de sujeição do discurso é a apropriação social. O indivíduo, através da educação, pode ter acesso a qualquer tipo de discurso, porém o sistema de ensino é uma maneira política de manter ou modificar a apropriação dos discursos. De acordo com Foucault:

O que é afinal um sistema de ensino senão uma ritualização da palavra; senão uma qualificação e uma fixação dos papéis para os sujeitos que falam; senão a constituição de um grupo doutrinário ao menos difuso; senão uma distribuição e uma apropriação do discurso com seus poderes e seus saberes? (FOUCAULT, 2005, p. 44-45).

Podemos parafrasear a afirmação foucaultiana dizendo que o sistema familiar, visto como um sistema de ensino com seus ritos e doutrinas, é uma maneira política de manter ou dominar os discursos e, por conseguinte, os sujeitos. Segundo o protagonista André, o pai quer transformar a família em uma 'escola de meninos-artesãos', onde tudo é cultivado e produzido em casa. Porém, mais que uma questão particular de trabalho, trata-se de uma política do exercício do seu poder, em que o pai quer impor o seu discurso, fazendo da instituição familiar uma instituição de ensino e aprendizagem. Ele quer ritualizar sua palavra, constituir um grupo doutrinário das suas leis, fixar papéis para cada membro familiar, além de impor a todos a apropriação de suas palavras com vistas à manutenção e à difusão dos seus ensinamentos. Para isso, faz uso de um tipo de poder chamado disciplina. Uma modalidade constituída por um conjunto de instrumentos, procedimentos, técnicas e níveis de aplicação que permite exercer o poder de forma efetiva.

Através do seu discurso, Iohána pratica o exercício do seu poder. Tal poder é exercido na tentativa de moldar os sujeitos conforme os padrões tradicionais herdados. No diálogo com Pedro, André afirma que o pai: 
Na sua sintaxe própria, dura e enrijecida pelo sol e pela chuva, era esse lavrador fibroso catando da terra a pedra amorfa que ele não sabia tão modelável nas mãos de cada um; [...] mas era assim que ele queria as coisas, ferir as mãos da família com pedras rústicas, raspar nosso sangue como se raspa uma rocha de calcário (NASSAR, 2005, p. 42).

\section{O ENFERMIÇO E PROFANO LADO ESQUERDO: ANDRÉ}

André tem consciência da tentativa do pai de querer modelar a família, castrando os desejos e pulsões do corpo de cada um. E é em nome do seu desejo que ele quer se libertar desse tirano totalitário. Dessa forma, é "contra a negação da carne, cheia de fome e de desejos, que se insurge o filho." (PERRONE-MOISÉS, 1996, p. 64). Como o discurso do pai simboliza o poder, é justamente esse discurso que André vai atacar ao problematizar uma ordem instituída. Segundo Rodrigues, o discurso do pai prega o comedimento e a moderação, porém, a performance de sua fala se apresenta como descomedida, repetitiva e excessiva. "O que já não pode mais ser obtido unicamente pela presença requer a palavra persuasiva a acompanhá-la. E a insuficiência dessa palavra primeira requer outras e mais outras e assim sucessivamente." (RODRIGUES, 2006, p. 40). A presença do pai já não é suficiente para a manutenção da ordem, por isso a insistência da repetição dos seus sermões é uma forma de convencer a família a aceitálos como uma norma. Em vários momentos da narrativa, André denuncia e critica a hipocrisia desse discurso, afirmando serem "inconsistentes os sermões do pai" (NASSAR, 2005, p. 47), uma vez que o que ele falava era dito "provavelmente sem saber o que estava dizendo" (NASSAR, 2005, p. 41-42). O discurso do pai não alcançava a família. Petrificado e repleto de frases feitas retiradas de textos compilados, seu discurso, de acordo com André, era formado simplesmente por "discernimentos promíscuos [...] em que apareciam enxertos de várias geografias" (NASSAR, 2005, p. 89).

O embate divergente entre o discurso paterno e o discurso de André é evidente em toda a narrativa. O pai é inscrito na narrativa como instaurador da lei, fundamentado sempre na tradição, é o responsável pela perpetuação da mesma. Já o filho, alicerçado nos desejos de sua carne, inscreve-se como transgressor dessa lei e dessa ordem, instaurando o caos e a desordem.

André tem uma fome impossível de ser apaziguada e saciada. Uma fome profana e obscena. Conhecedor da lei sagrada, reverte-a derramando o sangue de Cristo no lamaçal vulcanizado que tem dentro de si. Joga todos os valores religiosos na lama; nessa lama vulcânica que é o seu corpo, pronta para entrar em erupção e explodir: "Eu, o epilético, o possuído, o tomado, eu, o faminto, arrolando na minha fala convulsa a alma de uma chama, um pano de verônica e o espirro de tanta lama, misturando no caldo deste fluxo o nome salgado da irmã, o nome pervertido de Ana" (NASSAR, 2005, p. 110).

André quer liberar o fluxo da vida, quer incendiar o mundo e amenizar a sua fome, mas para isso ele precisa do seu complemento, ou melhor, do seu alimento: "era Ana, Pedro, era Ana a minha fome” (NASSAR, 2005, p. 107). Ana é o sal, o tempero, o 
alimento que dá sentido à existência de André. No entanto, o pai é o obstáculo que o impede de saciar essa fome. Como "senhor da mulher e da prole" (DUPUIS, 1989, p. 137), o pai é o empecilho à concretização do seu desejo e também dos desejos de toda a família. O cesto de roupa suja era o ossuário desses desejos reprimidos e, conforme André, tão bem conhecidos por ele, já que ninguém afundou tanto as mãos ali como ele:

Era o pedaço de cada um que eu trazia nelas quando afundava minhas mãos no cesto, ninguém ouviu melhor o grito de cada um, [...] bastava afundar as mãos pra colher o sono amarrotado das camisolas e dos pijamas e descobrir nas suas dobras, ali perdido, a energia encaracolada e reprimida do mais meigo cabelo do púbis, e nem era preciso revolver muito para encontrar as manchas periódicas de nogueira no fundilho dos panos leves das mulheres ou escutar o soluço mudo que subia do escroto engomando o algodão branco e macio das cuecas (NASSAR, 2005, p. 42-43).

Enquanto a casa dormia, André percorria corredores e mergulhava no cesto de roupa suja em busca de vestígios, de detalhes íntimos da família. As vestes sujas encontradas no cesto, com suas marcas e aromas, revelavam a esse arguto protagonista o corpo dessa família, com seus desejos secretos e reprimidos, suas buscas solitárias pelo prazer e os gritos e gemidos de solidão. As portas, mesmo fechadas, revelavam o seu interior. André dizia poder ouvir "as pulsações, os gemidos e a volúpia mole dos nossos projetos de homicídio" (NASSAR, 2005, p. 43-44). Com isso, o narrador afirma conhecer melhor a família que qualquer outra pessoa daquela casa, que ninguém amou mais do que ele aquela família.

Posicionando-se como o conhecedor dos conflitos, das dores e dos desejos reprimidos da família, André se coloca como aquele que quer libertar os familiares da palavra doentia do pai, que os impedia de matar sua fome e sua sede. Esse 'herói' ao avesso ridiculariza, ironiza e nega o discurso paterno. Para ele, o arroto tosco do avô valia muito mais que os discernimentos promíscuos do pai, bem como a sua "loucura era mais sábia que a sabedoria do pai” (NASSAR, 2005, p. 109).

André não se deixa arregimentar pelo pai e se coloca como o eu (sujeito) do seu discurso. Impõe-se como o oleiro do seu próprio barro: "eu sou um epilético fui explodindo, [...] sabendo que atirava numa suprema aventura ao chão, descarnando palmas, o jarro da minha velha identidade elaborado com o barro das minhas próprias mãos" (NASSAR, 2005, p. 39). Da mesma forma que o pai não reconhece outro discurso que não seja o seu, André também não reconhece outra ciência que não seja a sua. Ao revelar a Pedro a relação incestuosa com Ana, sua transgressão mais séria contra a lei familiar, André, "virando a mesa dos sermões num revertério, destruindo travas, ferrolhos e amarras, tirando não obstante o nível, atento ao prumo, erguendo um outro equilíbrio" (NASSAR, 2005, p. 109) quer mostrar que outro discurso e, por conseguinte, outra lei pode ser seguida: a sua. Ao mandamento de manter-se dentro dos limites da fazenda e ao consequente desapego do mundo das paixões, André responde transgredindo as divisas da propriedade, quando seu corpo incendiado rompia o arame farpado das cercas indo para prostíbulos, onde se deixava cair na fervura insana desses caldeirões: "era lá, Pedro, era lá que eu, escapulindo da fazenda nas noites mais quentes e banhado em fé insolente, comungava quase estremunhado" (NASSAR, 2005, p. 69). 
André quer construir a própria catedral e criar as próprias leis. Não só diferenciando-as das leis impostas pelo pai, mas, sobretudo, contradizendo-as: "sobre esta pedra fundarei minha igreja particular, a igreja para o meu uso, a igreja que frequentarei de pés descalços e corpo desnudo" (NASSAR, 2005, p. 87). Essa contestação irônica em relação aos ensinamentos do pai está presente desde a primeira frase do livro, "os olhos no teto", contrariando o discurso do pai que afirmava que ninguém naquela casa deveria começar nada pelo teto: "começar pelo teto é o mesmo que eliminar o tempo que se levaria para erguer os alicerces e as paredes de uma casa” (NASSAR, 2005, p. 53). Mas André não está interessado em construir alicerces e paredes sólidas, ao contrário, ele quer "agitar os alicerces, pôr em vibração as paredes" (NASSAR, 2005, p. 66), instaurar uma nova ordem, trilhando seu caminho contra o curso dos ventos; decreta: "a impaciência também tem seus direitos" (NASSAR, 2005, p. 88), contrariando o desígnio do pai de que a paciência é a maior das virtudes. Seguindo contra a advertência do comedimento, "ai daquele que queima a garganta com tanto grito" (NASSAR, 2005, p. 55), André convoca: "vamos pôr grito neste rito" (NASSAR, 2005, p. 66). E opondose à negação das paixões, ele diz: "eu era inteiro um lastro em carne viva" (NASSAR, 2005, p. 135-136) e conclama: "vamos incendiar o mundo!" (NASSAR, 2005, p. 106).

\section{CONCLUSÃO}

André é a figura do dissenso. Da impossibilidade da comunicação e da obediência. Retrato de um marginal abandono às forças intempestivas da paixão. Se a transgressão e as palavras pronunciadas por André soam como blasfêmia, isso indicaria para o pai uma doença, uma enfermidade: "nesta mesa não há lugar para provocações, deixe de lado o teu orgulho, domine a víbora debaixo da tua língua, não dê ouvidos ao murmúrio do demônio, me responda como deve responder um filho..." (NASSAR, 2005, p. 167). Mas, contrariamente, a impressão é a de que André experimenta uma grande saúde, "na minha doença existe uma poderosa semente de saúde" (NASSAR, 2005, p. 160).

A desubjetivação de André ocorre justamente por um conjunto de problemas que o envolve, o corta e o transfigura. André é o agenciamento por repetição: discurso litúrgico, moral, sermões, normas, leis, fundamentos. Mas, também, é uma heterogeneidade que recusa o antigo mundo, o antigo pertencimento. Não há mais uma mera representação de valores, mas uma potência sem identidade, explodindo sentido e desejo. Anárquica mistura física, social e biológica. André é o efeito do desejo. Sua dobra mais radical. Sua expressão mais efetiva. Apesar do silêncio de Ana, que se consome pela culpa e pelo medo, iluminados por uma religiosidade e uma crença arraigada, a paixão entre eles permanece. E a vazão a este desejo desencadeará um trágico final. Enquanto André, na impossibilidade comunicativa com o pai, tentava reconstruir uma estrutura que desmoronava a cada argumento, Ana desaparecia, não para resguardar a lei ou a ordem, mas para remoer no silêncio o prazer pelo vivido, as pulsões mais escondidos. Ana é a imagem sombria e precursora do corte, da vertigem, daquilo que é assustador nas pessoas, do desejo que quer satisfação e que explode num ultimo instante, invadindo e transcorrendo de forma volúvel e cheia de êxtase o espaço 
da festa, onde a família e a comunidade festejavam o retorno do filho insano. Ana, elemento diferenciante, manteve-se distante do embate entre André e o Pai no decorrer do romance, mas reaparece de forma intempestiva no final do texto. Esse "aparecer/acontecer" é uma resposta a André. Um rasgo de alegria à paixão que ambos se entregaram, "Ana (que todos julgavam sempre na capela) surgiu impaciente numa só lufada, os cabelos soltos espalhando lavas" (NASSAR, 2005, p. 186).

\begin{abstract}
Varando com a peste no corpo, o circulo que dançava, introduzindo com segurança, ali no centro, sua petulante decadência, assombrando os olhares de espanto, suspendendo em cada boca o grito, paralisando os gestos por um instante, mas dominando a todos com seu violento ímpeto de vida (NASSAR, 2005, p. 186-187).
\end{abstract}

É a Ana da desmedida. Dos exageros que transborda e desassossega. Indócil. Febril. Mergulho indizível pela alma e pelo corpo. Sem gênese e sem fim. Entre a dança solar de Ana e a agonia telúrica de André, haverá o mergulho de um fôlego só. Inflexível. Humano. Intransigente. Se Ana anteriormente foi indiferente pelo silêncio, agora, com a sua dança, ela afaga André. Faz-lhe um carinho:

\begin{abstract}
Eu estava certo, mais certo do que nunca, de que era para mim, e so para mim, que ela dançava (que reviravoltas o tempo dava! Que ossos, que espinho virulento, que gloria para o meu corpo!), e eu, sentado onde estava sobre uma raiz exposta, num canto do bosque mais sombrio, eu deixei que o vento que corria entre as arvores me entrasse pela camisa e me inflasse o peito, e na minha fronte eu sentia a caricia livre dos meus cabelos [...]. (NASSAR, 2005, p.189).
\end{abstract}

Simultaneamente a essa apoteótica expressão, que reduzia tudo à tolice: ensinamentos, parâmetros, referências, paradigmas, um outro sentimento se alimentava e entorpecia o que outrora era conhecido por temperança, equilíbrio e razão. Carregado de ódio e paixão, o patriarca, voz audível entre o passado e o presente, muralha robusta que dividia a vida entre a verdade e o erro, desfaz-se do manto sagrado da compreensão e do entendimento. Deixa cair ao solo arcaico de sua lavoura todas as máscaras que o tempo não fora capaz de destruir.

[...] A testa nobre de meu pai, ele próprio ainda úmido de vinho, brilhou um instante à luz morna do sol enquanto o rosto inteiro se cobriu de um branco súbito e tenebroso, e a partir daí todas as rédeas cederam, desencadeando-se o raio numa velocidade fatal: o alfanje estava ao alcance de sua mão, e, fendendo o grupo com a rajada de sua ira, meu pai atingiu com um só golpe a dançarina oriental (que vermelho mais pressuposto, que silêncio mais cavo, que frieza mais torpe nos meus olhos!) [...] Mas era o próprio patriarca, ferido nos seus preceitos, que fora possuído de cólera divina (pobre pai!), era o guia, era a tabua solene, era a lei que se incendiava (NASSAR, 2005, p. 191).

A insuportabilidade de uma verdade travestida pelos engodos de uma historia, do tempo, dos hábitos. Como fala André, "pobre família nossa, prisioneira de fantasmas tão consistentes!" (NASSAR, 2005, p. 191). É dessa maneira que o romance de Raduan Nassar finaliza a tessitura das relações. Nada é tão rígido. Nada é tão inflexível. A vida se consolida num composto de agenciamentos onde o indeterminável, o estranho, 
estrangeiro morador das casas, das famílias, vai fazendo a sua melodia. Podemos chamá-lo de desejo. Talvez denominá-lo de sombria natureza humana que constrói silenciosamente os personagens, virtualmente, aguardando o instante, o dispositivo ou uma série qualquer para o seu aparecimento. No final, André, Ana e o Pai, todos são traidores. Se os dois primeiros traem o mundo das significações e transgridem uma ordem estabelecida, o Pai deixa-se sucumbir pela verve furiosa da paixão, tornando-se "outro", perdendo a sua identidade, seu rosto. Nesse jogo movediço, todos desaparecem por entre as leis das determinações objetivas. Nesse novo teatro, não há mais segredo. Já não há fantasia, mas apenas programas de vida, sempre modificados à medida que se fazem traídos à medida que se aprofundam como riachos que desfilam ou canais que se distribuem para que corra um fluxo (NASSAR, 2005, p. 61).

No fim do romance não há mais sujeitos. Não há mais estrutura. Um tipo de naufrágio do ego ou o fim da antinomia entre corpo e espírito (razão). Em André, Ana e o Pai, a vida silenciosamente lapidava as condições que os tornariam tão próximos pela ação da desrazão. Se, para Ana, a morte a aguardava pelo caminho da paixão, no Pai, a morte o espreitava pela via da loucura. Não há mais um olhar atento e vigilante da alma, e todos, em suas dessemelhanças, se assemelham. Tornam-se um, elementos de um mesmo teatro e impulsionados para a mesma direção: das afecções, das paixões e do excesso.

\section{REFERÊNCIAS}

ABATI, Hugo Marcelo Fuzeti. Da Lavoura Arcaica: Fortuna Crítica, Análise e Interpretação da Obra de Raduan Nassar. 1999. Dissertação (Mestrado em Estudos Literários). Curitiba, Universidade Federal do Paraná.

BENVENISTE, Émile. Problemas de linguística geral I. Trad. Maria da Glória Novak e Maria Luisa Néri. 4. ed. São Paulo: Pontes, 1995.

BLANCHOT, Maurice. A voz narrativa (o eu, o neutro). In: A conversa infinita 3: a ausência do livro, o neutro o fragmentário. Trad. João Moura Jr. São Paulo: Escuta, 2010.

COSTA, Jurandir Freire. A inocência e o vício: estudos sobre o homoerotismo. Rio de Janeiro: RelumeDumará, 1992.

DUPUIS, Jacques. Em nome do pai: uma história de paternidade. São Paulo: Martins Fontes, 1989.

FOUCAULT, Michel. A ordem do discurso. Trad. Laura Fraga de Almeida Sampaio. 12. ed. São Paulo: Edições Loyola, 2005.

Microfísica do Poder. Trad. Roberto Machado. 4 ed. Rio de Janeiro: Graal, 1984.

LIMA, Thayse Leal. O mundo desencantado: um estudo da obra de Raduan Nassar. 2006. Dissertação (Mestrado em Estudos Literários). Belo Horizonte, Universidade Federal de Minas Gerais.

NASSAR, Raduan. Lavoura arcaica. São Paulo: Companhia das letras, 2005.

PERRONE-MOISÉS, Leyla. Da cólera ao silêncio. In: Cadernos de Literatura Brasileira: Raduan Nassar, Rio de Janeiro, n. 2, Instituto Moreira Salles, 1996.

RODRIGUES, André Luis. Ritos da paixão em Lavoura Arcaica. São Paulo: Editora da Universidade de São Paulo, 2006.

ROUANET, Paulo Sérgio. Razão e paixão. In: Os sentidos da paixão. Org. Adauto Novaes. São Paulo: Companhia das Letras, 1990.

SEDLMAYER, Sabrina. Ao lado esquerdo do pai. Belo Horizonte: Editora UFMG, 1997.

TACCA, Oscar. As vozes do romance. Tradução de Margarida Coutinho Gouveia. 2 ed. Coimbra:

Livraria Almedina, 1983. 
Recebido em 21/01/2015. Aprovado em 19/05/2015.

Title: Discourse and power relations in Lavoura Arcaica, by Raduan Nassar

Abstract: The proposal of the article is dealing with the issue of discourse and power relations in the work Lavoura Arcaica by Raduan Nassar. We intend to develop the text making a contexture with the thought of Michel Foucault (knowledge, power, discourse). In the novel, we will present in particular the clash between father and son, both representing particular forms of ways of life, showing us antithetical aspects that permeate the narrative: the sacred and the profane, tradition and modernity, reason and passion. Both in Raduan Nassar literature, as in the thought of Michel Foucault, the subject is constituted in terms of discourses and power exercise that involves and entails it making bodies and producing identities. It is this subject and its possible dissolution which will be our object.

Keywords: Knowledge. Power. Discourse. Subject. Transgression. 